\title{
MEASURING INSTRUMENT FOR REFILLED DRINKING WATER USING A TDS SENSOR
}

\author{
Dudi Adi Firmansyah ${ }^{1, *}$, Kamila Rofa Khairunnisa Ibadurrohman ${ }^{1}$, \\ Bernadus Bisma Titis Restu Aji ${ }^{1}$, Suprijanto ${ }^{2}$
}

${ }^{1}$ D3 Metrology and Instrumentation, Academy of Metrology and Instrumentation, Jalan Daeng M. Ardiwinata km 3,4 Cihanjuang, Bandung Barat 40559, Indonesia

${ }^{2}$ Engineering Physics, Institute of Technology Bandung (ITB), Jalan Ganesha 10, Bandung 40132, Indonesia

*Corresponding Author Email: dudiaf1983@gdrivepro.com

Received: 20 June 2020

Revised: 21 August 2020

Accepted: 22 August 2020

Online: 31 August 2020

Published: 31 August 2020

SPEKTRA: Jurnal Fisika dan Aplikasinya p-ISSN: 2541-3384 e-ISSN: 2541-3392

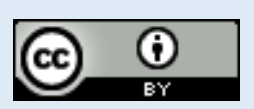

\begin{abstract}
Water is an essential need for humans and consumed as drinking water after fulfilling the health requirement in the Republic of Indonesia Minister of Health Regulation No.492/Menkes/Per/IV/2010. Due to the increasing demand, there are currently many refilled drinking water stores as an economical and practical alternative way to people. However, their safety still needs to be tested in the laboratory. This condition is impractical so that it needs a portable measuring instrument especially based on the TDS sensor that can measure the total dissolved solids (TDS) and electrical conductivity (EC) at once, which determines the taste and safety of the water. TDS sensor calibration at 80.5 to 966 ppm shows a $93.4 \%$ accuracy; $99.8 \%$ precision and $1.3 \mathrm{ppm}$ hysteresis. In comparison, EC calibration at 161 to 1932 microsiemens/cm produces an average of $82.3 \%$ accuracy, $97.1 \%$ precision, and 1.0 microsiemens/cm hysteresis. This prototype is then employed to measure the water sample and determine its safety to consume and observed a decreasing trend of TDS and EC (194.1 ppm and 388.2 microsiemens/cm) as compared to the water spring sample (20.2 ppm and 402.3 microsiemens $/ \mathrm{cm}$ ). The prototype also has a Bluetooth module that enabling the remote observation on a cell phone without the presence of a telephone network.
\end{abstract}

Keywords: refilled drinking water, TDS sensor, TDS, Bluetooth 


\section{INTRODUCTION}

Water is a critical need for all living things, including humans [1]. To humans, water is used in various activities starting from a basic need such as for drinking, cooking, and washing [2] to other needs such as for agriculture [3], industry [4], electricity [5], and others [6]. Amongst all these needs, the most important is for drinking water, since the human body consists mostly of water $[7,8]$. This need is generally fulfilled in two ways, i.e. (i) boiling the groundwater and tap water, and (ii) by the direct drinking water such as bottled drinking water and refilled drinking water depots [2,7]. Increasing pollution of the groundwater and the river has made this water less safe to be used as a raw material of drinking water $[9,10]$. Therefore, the need for direct drinking water motivates the emergence of various drinking water businesses, such as bottled drinking water (BDW) and refilled drinking water (RDW) [2,7,9]. However, the high price of bottled drinking water drives people to seek more affordable drinking water, namely RDW [2,7-9]. The RDW is one type of water that can be drunk directly without having to be cooked first, because it has been processed through several stages such as ultraviolet irradiation, ozonation, and reverse osmosis [2,11].

Despite its practicality, RDW's quality is still widely doubted. This is due to several things such as the lack of standardization in the regulation of water treatment processes, the quality of raw water, hygiene and sanitation of the depot, type of processing processes, types of equipment, and their maintenance such as filters that are rarely replaced, expired of the passed certificate of the water quality laboratory test, the behavior of the depot officer who has no awareness to clean and healthy living behavior [2,7-9]. Under these conditions, the produced RDW may become a dangerous risk to the health because of the contamination of pathogenic bacteria [7-9,11] and high concentrations of several heavy metals $[12,13]$. Therefore, to ensure its safety, the RDW must be measured its quality in a laboratory and compared the results with the health requirements of drinking water as regulated by Permenkes Number 492/Menkes/Per/IV/2010. Nevertheless, this method is, of course, ineffective and inefficient considering a large number of depots to be inspected [1,2,7-9,11-13] and the testing frequency, which must be held at least once a month for physical and microbiological parameters, and every six months for chemical parameters according to regulations [8]. Therefore, a measuring tool that can measure the quality of drinking water in a short time can be a solution to this problem. One of the critical parameters of drinking water quality is the total dissolved solids (TDS) because it affects the taste and safety of water to drink [14-17]. The high value of TDS may cause poisoning, discomfort in the sense of taste organ, and nausea $[14,15]$.

Measurement of TDS is generally performed by a TDS sensor that principally works based on the conductivity [14-16,18] and the optical properties of the solution [19,20]. The TDS measuring instrument with the principle of conductivity is worked by dipping two probes into the measured solution. The electrical signal, which is proportional to the conductivity of the solution, is converted into a TDS value through a linear equation and conditioning its electrical signal against the TDS input [14-16]. At the same time, the TDS measuring devices with the optical principle is worked by measuring the turbidity voltage value of an electrolyzed water sample that is passed between the receiver and transmitter $[19,20]$. TDS measuring devices with the principle of conductivity measurement were observed with smaller measurement 
errors of $1.1 \%$ to $5.2 \%$ [14-16] as compared to the optical TDS measuring devices made with error ranges of $1 \%$ to $22.6 \%[19,20]$. Also, the TDS measuring instrument with optical measurements is impractical because water samples must be electrolyzed to precipitate dissolved ions to be observed as turbidity [19,20]. Then, measuring TDS with the principle of conductivity is considered to be more comfortable because it can measure TDS directly on water samples [14-16], including for the remote monitoring of the water sample's quality directly by sending an SMS [16]. Also, an intelligent, IoT based water quality monitoring system was developed by employing a $\mathrm{pH}$ and TDS sensor [21]. However, in these devices, sending data takes a long time and still requires a telephone network or an internet network $[16,21]$ that making it less practical. One of the device communication methods that does not require a telephone network connection and its transmission time is fast enough is Bluetooth [22]. Therefore, in this study, a measuring instrument prototype for TDS and electrical conductivity (EC) will be assembled because the sensor used in this study is working with the conductivity principle $[14,16,18]$. This prototype also can send the measurement results without the need for cellular phone networks through a Bluetooth module, and its sensor will be tested with a standard solution because the previous studies calibrated the sensor without the standard solution [14-16,19,20]. This prototype instrument is then employed to test the RDW samples in the field.

\section{METHOD}

This research is carried out in three stages, i.e., the assembling of the prototype for measuring the quality of refilled drinking water, testing of the prototype, and measuring of RDW samples in the field. The prototype is assembled from several components such as an on/off switch, $9 \mathrm{~V}$ battery, TDS sensor, RTC module, Arduino Uno, LED indicators, LCD, Bluetooth module, and smartphone. These components are arranged according to the prototype block diagram, as shown in FIGURE 1 (a). The working principle of this prototype measures the TDS and EC values from samples solution as an analog signal with a TDS sensor [23] that will be converted into a digital signal with an Analog TDS Module [23]. Subsequently, these digital signals are processed by a microcontroller (Arduino Uno) [20], and the results are shown in an LCD, LED indicators, and smartphone sent by a Bluetooth module [22]. These results consist of TDS value, EC value, and time obtained from the RTC digital module [24].

The second step is testing the prototype with TDS and EC standards solution. The standard solution of TDS that is utilized in this work is the TDS standard solution of $6440 \mathrm{ppm}$, which is diluted to 5 (five) levels of TDS concentration, i.e., 80.5 ppm; 161 ppm, 322 ppm; 644 ppm, and $966 \mathrm{ppm}$. In EC testing, the standard solution used is the EC standard solution of 5446 $\mu \mathrm{S} / \mathrm{cm}$, which is diluted into five standard levels of EC concentration, i.e., $161 \mu \mathrm{S} / \mathrm{cm}, 322$ $\mu \mathrm{S} / \mathrm{cm}, 644 \mu \mathrm{S} / \mathrm{cm}, 1288 \mu \mathrm{S} / \mathrm{cm}$, and $1932 \mu \mathrm{S} / \mathrm{cm}$. Then, testing of the prototype measurement characteristics is performed by measuring the TDS value of each standard solution as many as 30 times in the increasing and decreasing test conditions, so that the linearity, accuracy, precision, and hysteresis values of the sensor can be determined from the change in input TDS value. Then, in the same way, the measurement characteristics of the prototype sensor are tested against the changes in the input of EC value in each EC standard solution. Then, in the 
third stage, the prototype is employed to measure the value of TDS and EC in the field i.e., the sample of refilled drinking water and raw water source for refill depots in the North Cimahi region.

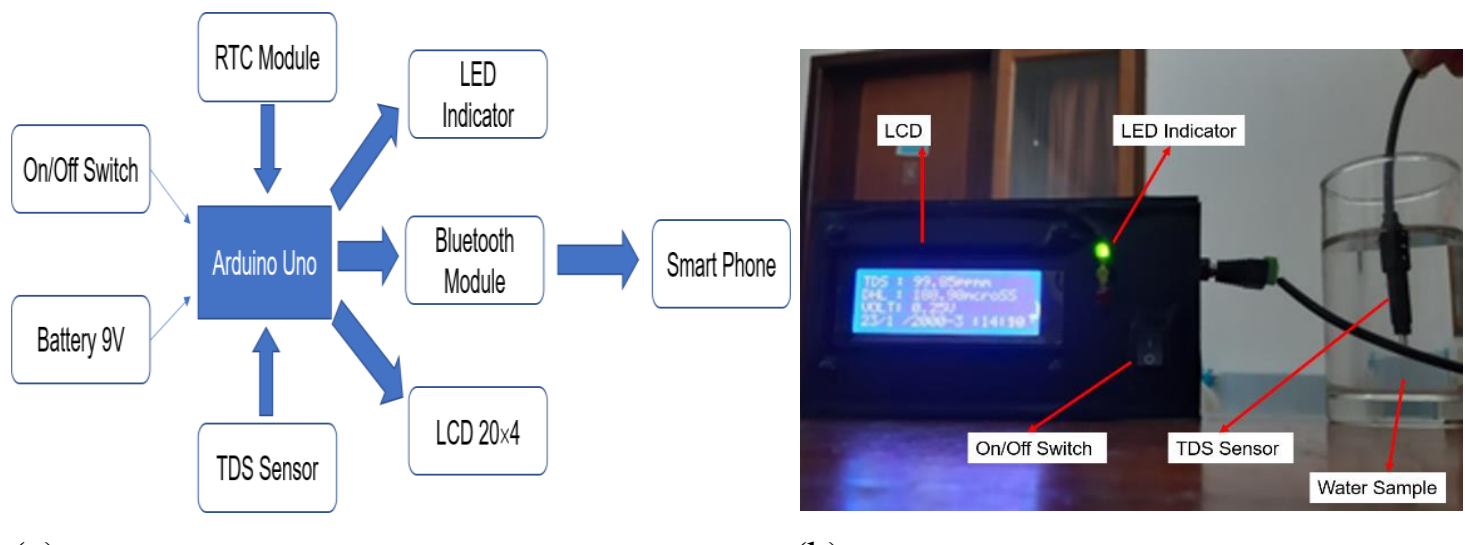

(a)

(b)

FIGURE 1. Prototype of measuring instrument for refilled drinking water: (a) block diagram of design, and (b) assembled result.

\section{RESULT AND DISCUSSION}

The result of the assembled prototype for measuring the quality of refilled drinking water is shown in FIGURE 1 (b). On the front of the prototype, there are three parts, i.e., an LCD, LED indicators, and an on/off switch button, while on the side of the prototype, there is a TDS sensor port which connects to a TDS sensor for measuring the TDS and EC values of the sample. The LCD shows several data values such as the TDS, EC, the output voltage from the sensor, and the date and time of the measurement. Whereas the LED indicator, consisting of three colors, namely green, yellow and red, is adjusted to the safety requirements of drinking water samples according to the TDS value regulated in Permenkes RI Number 492/Menkes/Per/IV/2010. Therefore, the meaning of those indicators is related to the drinking water quality, i.e., the red for very bad quality, the yellow for good quality, and the green for very good quality. The prototype is also portable, that powered with a battery equipped with an on/off switch button, to facilitate the measurement of the sample in the field.

The first results are the testing results of the prototype on measuring five standards TDS solution in the concentration range of $80.5 \mathrm{ppm}$ to $966 \mathrm{ppm}$. As shown in TABLE 1, the results show that the prototype is capable of indicating the closer values to the TDS standard value [25] as observed from the overall accuracy average of $93.8 \%$ and the accuracy values of $82.28 \%$ to $98.1 \%$ calculated from the average value of the accuracy of upward and downward measurement at each measurement point. While in a precision term, the prototype can perform a reasonably consistent measurement when measured with the same TDS standard solution with an average precision value of $99.8 \%$. Those results are consistent with the previous studies $[15,16]$. Also, by comparing the RSD value of $0.05 \%$, which is much smaller than the $2 / 3 \mathrm{CV}$ Horwitz value of $4.5 \%$, this prototype is validated to have a high degree of precision [25]. Furthermore, by observing many similar values in the result at the same TDS value 
during the upward and downward measurement, this prototype yields a hysteresis value of 1.3 ppm or $0.13 \%$ of the highest TDS standard value. With this small hysteresis value, the prototype exhibits a pretty good measurement performance [26].

TABLE 1. Testing results of the prototype using TDS standards solution.

\begin{tabular}{|c|c|c|c|c|c|c|c|}
\hline $\begin{array}{l}\text { TDS } \\
\text { Standard } \\
\text { Solution } \\
(\mathrm{ppm})\end{array}$ & $\begin{array}{l}\text { Upward } \\
\text { measurement } \\
(\text { ppm) }\end{array}$ & $\begin{array}{l}\text { Downward } \\
\text { measurement } \\
(\mathrm{ppm})\end{array}$ & RSD (\%) & $\begin{array}{l}2 / 3 \mathrm{CV} \\
\text { Horwit } \\
\mathrm{z}(\%)\end{array}$ & $\begin{array}{l}\text { Accuracy } \\
(\%)\end{array}$ & $\begin{array}{l}\text { Precision } \\
(\%)\end{array}$ & $\begin{array}{l}\text { Hysteresis } \\
(\mathrm{ppm})\end{array}$ \\
\hline 80.5 & 94.3 & 94.3 & $4.6 \times 10^{-14}$ & 5.4 & 82.8 & 100 & 0 \\
\hline 161 & 179.7 & 177.0 & 0.3 & 4.9 & 90.0 & 99.2 & 2.7 \\
\hline 322 & 319.9 & 319.9 & $5.4 \times 10^{-14}$ & 4.5 & 99.3 & 100 & 0 \\
\hline 644 & 653.7 & 653.7 & $3.5 \times 10^{-14}$ & 4.0 & 98.5 & 100 & 0 \\
\hline 966 & 949.8 & 946.2 & $3.1 \times 10^{-14}$ & 3.8 & 98.1 & 100 & 3.7 \\
\hline Average & & & 0.05 & 4.5 & 93.8 & 99.8 & 1.3 \\
\hline
\end{tabular}

The second results are the testing results of the prototype on measuring five standards of electrical conductivity (EC) solution in the concentration range of $161 \mu \mathrm{S} / \mathrm{cm}$ to $1932 \mu \mathrm{S} / \mathrm{cm}$. Even though EC is not specifically regulated in Permenkes RI No. 492/Menkes /Per/IV/2010, the high value of EC may cause water to become brackish until salty [27]. Unlike the previous TDS measurement results, the EC measurement results are less close to the standard EC solution values with an average accuracy from the whole measurement point is $82.3 \%$. This is due to the SEN0244 sensor as the prototype sensor previously used as a TDS sensor, even though its working principle is measuring the level of EC between two parallel iron bars in the solution [28]. Therefore, the measured value of EC from the prototype is not the main indicator of the safety of the refilled drinking water sample under the regulation of The Minister of Health. Despite that, the prototype still shows fairly enough performance in terms of precision and hysteresis $[25,26]$. In terms of precision, the average RSD value of $0.8 \%$ is still far smaller than the average value of $2 / 3 \mathrm{CV}$ Horwitz of $4.0 \%$, so that the prototype is validated to have a high degree of precision [25]. Whereas in terms of hysteresis, the prototype can generate similar EC values when measured the same EC standard solution, both in upward and downward measurement conditions, with a hysteresis value of $1 \mu \mathrm{S} / \mathrm{cm}$ or $0.05 \%$ from the highest standard EC value. This hysteresis value also shows that the prototype performance is good enough [26].

TABLE 2. Testing results of the prototype using EC standards solution.

\begin{tabular}{llllllll}
\hline $\begin{array}{l}\text { EC } \\
\begin{array}{l}\text { Standard } \\
\text { Solution } \\
(\mu \mathrm{S} / \mathrm{cm})\end{array}\end{array}$ & $\begin{array}{l}\text { Upward } \\
\text { Measurement }\end{array}$ & $\begin{array}{l}\text { Downward } \\
\text { Measurement } \\
(\mu \mathrm{S} / \mathrm{cm})\end{array}$ & $\begin{array}{l}\text { RSD } \\
(\%)\end{array}$ & $\begin{array}{l}2 / 3 \mathrm{CV} \\
\text { Horwitz } \\
(\%)\end{array}$ & $\begin{array}{l}\text { Accuracy } \\
(\%)\end{array}$ & $\begin{array}{l}\text { Precision } \\
(\%)\end{array}$ & $\begin{array}{l}\text { Hysteresis } \\
(\mu \mathrm{S} / \mathrm{cm})\end{array}$ \\
\hline 161 & 207.8 & 207.7 & 0.7 & 4.8 & 73.7 & 97.3 & 0.1 \\
322 & 395.5 & 395.1 & 0.4 & 4.3 & 78.8 & 98.4 & 0.5 \\
644 & 695.7 & 690.8 & 2.1 & 4.0 & 98.6 & 93.4 & 4.8 \\
1288 & 1564.6 & 1567.3 & 0.4 & 3.5 & 80.0 & 98.5 & -2.7 \\
1932 & 2350.7 & 2348.2 & 0.6 & 3.3 & 80.4 & 98.8 & 2.5 \\
\hline Average & & & 0.8 & 4.0 & 82.3 & 97.1 & 1.0 \\
\hline
\end{tabular}


To analyze further the hysterical characteristic, the measurement values in ascending and descending conditions in TABLE 1 and TABLE 2 are plotted against the concentration of the standard solution, and the results are shown in FIGURE 3. These two conditions yield measurement points that are very close to each other so that they generate two linear regression results lines, which are almost overlapped on the TDS measurement (FIGURE 3 (a)) and the EC measurement (FIGURE 3 (b)). These findings are consistent with the results of previous calculations, which show the prototype hysteresis in the measurement of TDS and EC are good enough [26]. In addition, FIGURE 3 also produces a linearity regression correlation coefficient (R) that indicate a quite strong relationship between input and output, written as $\mathrm{R}=0.9997$ for TDS (FIGURE 3 (a)) and R = 0.9988 for EC (FIGURE 3 (b) ) [29,26].

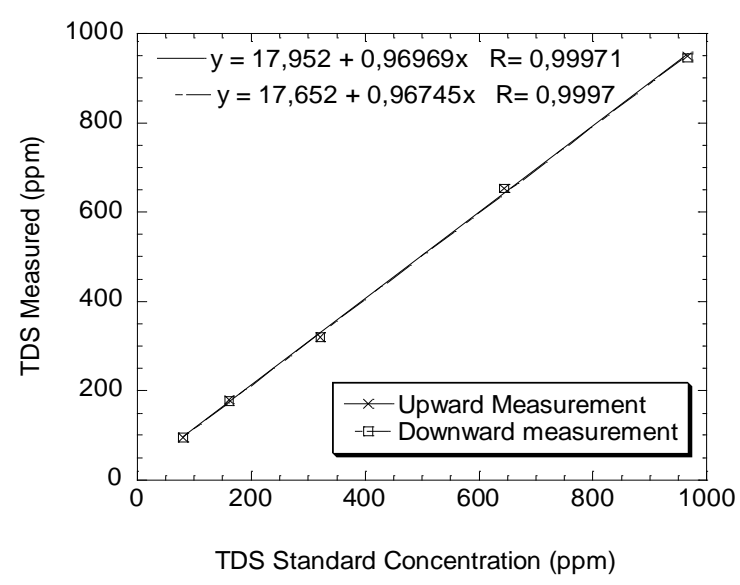

(a)

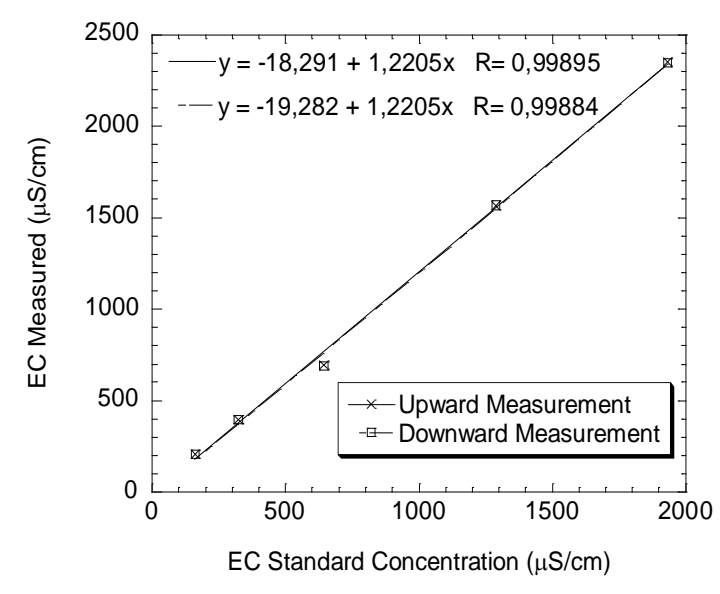

(b)

FIGURE 3. Graphs of upward and downward measurements of standard solutions: (a) TDS dan (b) EC.

Based on the previous results on TDS and EC tests that are reasonably good, the prototype is then employed to measure the quality of refilled drinking water samples in the field. The samples tested are refilled drinking water and raw water sources from the North Cimahi region. The measurement results are shown in FIGURE 4. As shown in this figure, the TDS and EC values of raw water decrease respectively from $201.2 \mathrm{ppm}$ to $194.1 \mathrm{ppm}$ (FIGURE 4 (a)) and 402.3 to $388.3 \mu \mathrm{S} / \mathrm{cm}$ (FIGURE 4 (b)) when processed in a refilled drinking water depot. Although the decrease of the two parameters is relatively small, these samples are still suitable as raw water and refilled drinking water based on the prevailing Health Minister Regulation. 


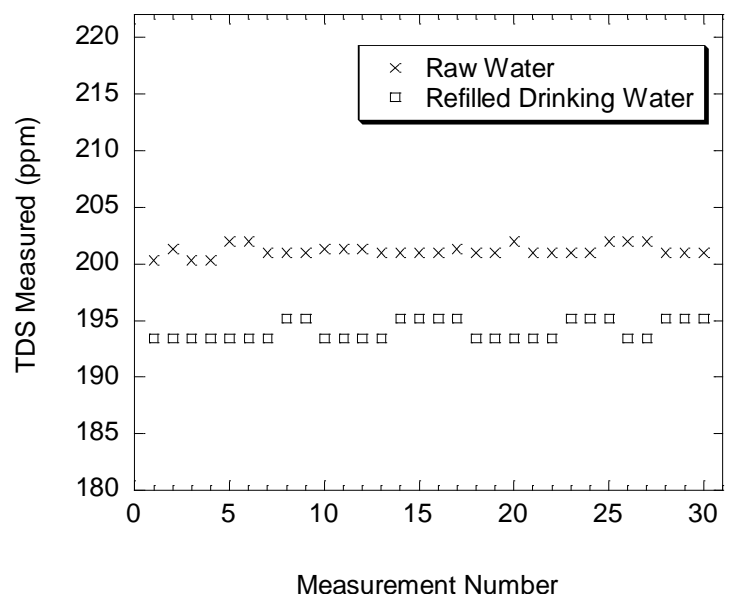

(a)

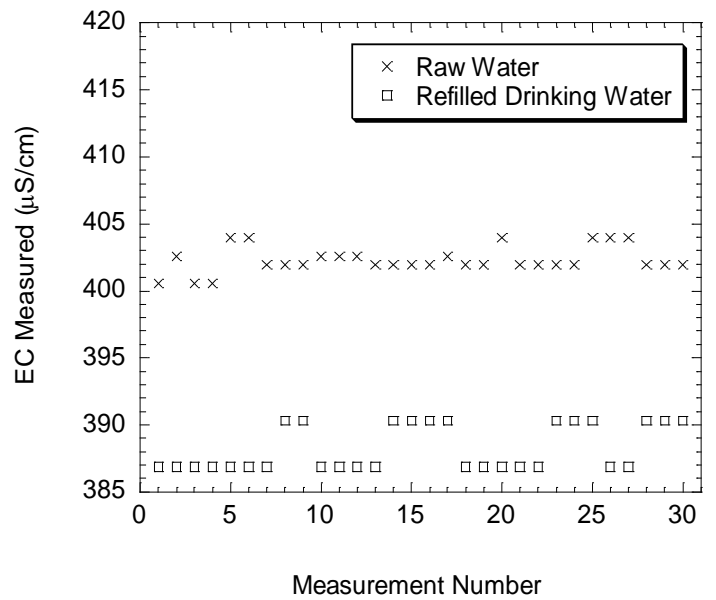

(b)

FIGURE 4. Measurement results of the field samples: (a) TDS values, dan (b) EC values.

This prototype employs an LCD, LED, and Bluetooth to display the measurement results. As shown in FIGURE 5 (a), the data displayed on the LCD consists of voltage (V), TDS (ppm), $\mathrm{EC}(\mu \mathrm{S} / \mathrm{cm})$ values, date, and time of measurement. The three different LED colors serve as a safety indicator for drinking water samples based on a range of TDS values, namely green (0 to $299 \mathrm{ppm}$ ), yellow (300 ppm to $499 \mathrm{ppm}$ ), and red (500 ppm to $1000 \mathrm{ppm}$ ). As shown in FIGURE 5 (a), the green LED light is consistent with the designed range of TDS values. Therefore, it can be stated that the prototype can measure the sample and indicate the safety of the water sample consistently under the prevailing Health Minister Regulation. To support the monitoring of drinking water samples wirelessly, the prototype was then tested for a connection with a Smartphone using the Bluetooth module. As a result, after one second, TDS, EC, and voltage values, which are shown in the LCD screen, can be sent and displayed on the Smartphone screen, as shown in FIGURE 5 (b).

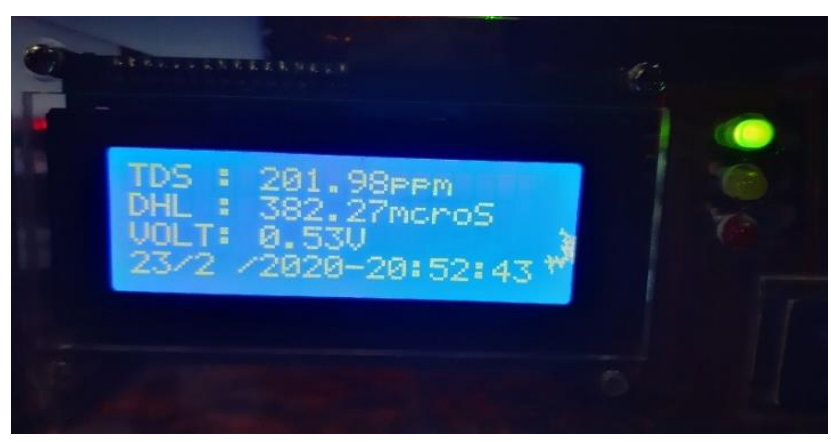

(a)

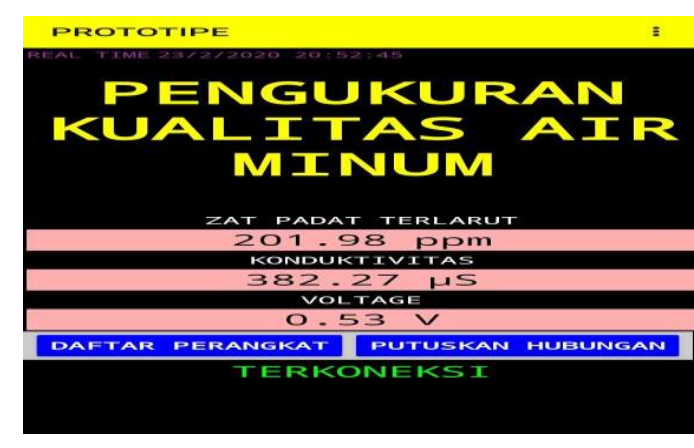

(b)

FIGURE 5. Prototype data displays : (a) LCD screen with LED indicator and (b) Smartphone screen connected by a Bluetooth Module. 


\section{CONCLUSION}

A prototype of refilled drinking water quality measuring instrument has been successfully made that can measure the value of TDS and EC from water samples and determine the safety of the water as indicated by the LED light according to the TDS value, and also the measurement results can be acquired to a Smartphone through a Bluetooth module. Test results with standard TDS solutions show the prototype has quite good performance with an accuracy of $93.8 \%$; $99.8 \%$ precision, and hysteresis $1.3 \mathrm{ppm}$. While the results of testing with the EC standard solutions, the prototype showed a fair performance with an accuracy of $82.3 \%, 97.1 \%$ precision, and hysteresis of $1.0 \mu \mathrm{S} / \mathrm{cm}$. With this performance, the prototype is then employed to measure several samples in the field, namely raw water and refilled drinking water samples from the North Cimahi region. As a result, the two samples have TDS and EC values below the regulated threshold, to indicate that the samples are safe to drink. Also, the prototype can send data wirelessly to Smartphones via a Bluetooth module within a very short time.

\section{ACKNOWLEDGMENT}

This research was funded from the Collaboration of Akmet (Academy of Metrology and Instrumentation) with Institue of Technology Bandung (ITB) in 2020. Acknowledgments were also delivered to the FTI ITB Physics Engineering and the Center for Development of Metrology Resources (PPSDK) - Ministry of Trade, which facilitated the implementation of this research.

\section{REFERENCES}

[1] M. Radji, H. Oktavia and H. Suryadi, "Pemeriksaan Bakteriologis Air Minum Isi Ulang Di Beberapa Depo Air Minum Isi Ulang Di Daerah Lenteng Agung Dan Srengseng Sawah Jakarta Selatan,” Majalah Ilmu Kefarmasian, 2012.

[2] D. I. Pratiwi, A. Harijanto and S. H. B. Prastowo, "Analisis Hubungan Daya Hantar Listrik dengan Total Dissolved Solid (TDS) pada Air Minum Isi Ulang di Sekitar Kampus Universitas Jember,” Seminar Nasional Pendidikan Fisika 2019, 2019.

[3] E. Pasandaran, "Reformasi Irigasi dalam Kerangka Pengelolaan Terpadu Sumberdaya Air,” Analisis Kebijakan Pertanian, 2017.

[4] Zulkipli, W. Soetopo and H. Prasetijo, “Analisa Neraca Air Permukaan DAS Renggung untuk Memenuhi Kebutuhan Air Irigasi dan Domestik Penduduk Kabupaten Lombok Tengah,” Jurnal Teknik Pengairan, 2011.

[5] A. Sugiyono, "Pemberdayaan Masyarakat dalam Mengelola Potensi Sumber Daya Air melalui Pengembangan Pembangkit Listrik Tenaga Mini/Mikro Hidro," Jurnal Ekonomi dan Studi Pembangunan, 2009.

[6] D. T. Y. Gaib, L. Tanudjaja and L. A. Hendratta, "Perencanaan Peningkatan Kapasitas Produksi Air Bersih Ibukota Kecamatan Nuangan,” Jurnal Sipil Statik, 2016.

[7] I. W. Latif, "Studi Kualitas Air Minum Isi Ulang Ditinjau Dari Proses Ozonisasi, Ultraviolet, dan Reversed Osmosis di Kecamatan KotaTengah dan Kecamatan Kota Selatan Kota Gorontalo Tahun 2012," Skripsi, Jurusan Kesehatan Masyarakat, Fakultas Ilmu-ilmu Kesehatan dan Keolahragaan, Universitas Negeri Gorontalo, 2012. 
[8] F. Melinda, S. Laili and A. Syauqi, "Uji Kualitas Air Minum Isi Ulang pada Depo Air Minum Di Sekitar Kampus UNISMA Malang," e-Jurnal Ilmiah BIOSAINTROPIS, 2017.

[9] M. D. O. Marpaung and B. D. Marsono, "Uji Kualitas Air Minum Isi Ulang di Kecamatan Sukolilo Surabaya Ditinjau dari Perilaku dan Pemeliharaan Alat," Jurnal Teknik POMITS, 2017.

[10] K. H. Kirana et al., "Sifat Magnetik Sedimen Sungai Sebagai Indikator Pencemaran (Studi Kasus: Sungai Citarum Kabupaten Karawang)," Spektra Jurnal Fisika dan Aplikasinya, 2014.

[11] A. W. Pratiwi, "Kualitas Bakteriologis Air Minum Isi Ulang di Wilayah Kota Bogor," KESMAS Jurnal Kesehatan Masyarakat Nasional, 2007.

[12] F. Tih, et al., "Kandungan Logam Timbal, Besi, dan Tembaga dalam Air Minum Isi Ulang di Kota Bandung," Zenit, 2015.

[13] S. Bali, "Kandungan Logam Berat (Timbal, Kadmium), Amoniak, Nitrit dalam Air Minum Isi Ulang di Pekanbaru," HEALTH CARE, 2012.

[14] Z. A. K. Sari, H. Permana and W. Indrasari, "Karakterisasi Sensor Photodioda, DS18B20, dan Konduktivitas Pada Rancang Bangun Sistem Deteksi Kekeruhan dan Jumlah Zat Padat Terlarut Dalam Air,” SPEKTRA Jurnal Fisika dan Aplikasinya, 2017.

[15] F. Amani and K. Prawiroredjo, "Alat Ukur Kualitas Air Minum dengan Parameter pH, Suhu, Tingkat Kekeruhan, dan Jumlah Padatan Terlarut,” JETRI, 2016.

[16] G. A. Putera and D. H. F. M. Christian, "Perancangan Alat Ukur Kadar Padatan Terlarut, Kekeruhan dan $\mathrm{pH}$ Air Menggunakan Arduino Uno," Skripsi Departemen Teknik Elektro Fakultas Teknik Unhas, 2017.

[17] R. Devesa and A. M. Dietrich, "Guidance for optimizing drinking water taste by adjusting mineralization as measured by total dissolved solids (TDS)," Desalination, 2018.

[18] S. Geetha and S. Gouthami, "Internet of things enabled real time water quality monitoring system," Smart Water, 2016.

[19] V. Aryanto, M. Rohmad and E. Puspita, "Sistem Pendeteksi Kelayakan Air Minum Dalam Kemasan ( AMDK ) Sebagai Solusi Alternatif BPOM Berbasis Mikrokontroler," EEPIS Final Project PEN Surabaya, 2010.

[20] I. Afandi and K. Amdani, "Rancang Bagun Alat Pendeteksi Kelayakan Air Minum Yang Diproduksi Depot Air Minum Isi Ulang (AMIU) Berbasis Mikrokontroler AT89S51 dan LCD Menggunakan Inframerah dan Photodioda sebagai Indikator,’ Jurnal Einstein, 2018.

[21] S. Pappu et al., "Intelligent IoT Based Water Quality Monitoring System," International Journal of Applied Engineering Research, 2017.

[22] A. Syofian, "Pengendalian Pintu Pagar Geser Menggunakan Aplikasi Smartphone Android dan Mikrokontroler Arduino Melalui Bluetooth," Jurnal Teknik Elektro ITP, 2016. 
[23] M. G. N. Eoh, J. Andjarwirawan and R. Lim, "Sistem Kontrol dan Monitoring pH Air serta Kepekatan Nutrisi pada Budidaya Hidroponik Jenis Sayur dengan Teknik Deep Flow Techcnique,” J. Infra, 2019.

[24] A. N. Pratama, "Implementasi Sensor TDS (Total Dissolved Solids) untuk Kontrol Air Secara Otomatis pada Tanaman Hidroponik," Skripsi S1 Program Studi Sistem Komputer STIKOM Surabaya, 2017.

[25] Torowati, Ngatijo and Rahmiati, "Validasi Metode Untuk Analisis Kandungan Uranium Menggunakan Potensiometer T-90," Prosiding Seminar Penelitian dan Pengelolaan Perangkat Nuklir, 2016.

[26] A. Wicaksono and I. D. W. Susanto, "Sistem Otomasi Penggerak Kamera dengan Motor Step sebagai Alat Bantu Kalibrasi Alat Ukur Panjang," Jurnal Otomasi Kontrol dan Instrumentasi, 2014.

[27] R. Mukarromah, "Analisis Sifat Fisis dalam Studi Kualitas Air di Mata Air Sumber Asem Dusun Kalijeruk, Desa Siwuran, Kecamatan Garung, Kabupaten Wonosobo," Skripsi Jurusan Fisika FMIPA UNNES, 2016.

[28] I. F. Furqaana, "Irrigation Scheduling Untuk Tanaman Selada Hidroponik dengan Metode NFT Menggunakan Arduino," Tugas Akhir Program Studi Teknik Informatika FTI UII, 2019.

[29] K. U. Ahamad et al., "Surface Water Quality Modeling by Regression Analysis and Artificial Neural Network," Advances in Waste Management Springer Singapore, 2019. 